\title{
Are Some Groups More Vulnerable to Business Cycle Shocks than Others? A Regional Analysis of Pakistan's Labor Market
}

\section{Mehak Ejaz* and Kalim Hyder**}

\begin{abstract}
This study identifies the extent to which various socioeconomic groups are vulnerable to aggregate business cycle fluctuations. Socioeconomic groups are classified by gender, location, employment status, education, income and age cohort. The asymmetric behavior of aggregate economic growth indicates that some groups gain less during recovery and boom phases and are thus most vulnerable to recessions. A vulnerability index in calculated for different socioeconomic groups and the empirical results show that employers with a graduate degree in Balochistan are the most vulnerable group and that female workers are more vulnerable than male workers. Additionally, the study employs panel data on inflation and employment to investigate the implications of macroeconomic fluctuations on vulnerable groups. The results indicate that food inflation has a strong negative impact on real earnings, while nonfood inflation increases real earnings. The panel data and vulnerability index findings are consistent with each other. The study also presents policy implications for existing public social safety net programs and prospective private social innovation programs targeting vulnerable households.
\end{abstract}

Keywords: Business cycle fluctuations, socioeconomic groups, vulnerability, GMM, Pakistan, real earnings, gender.

JEL classification: E24, E31, E32, J11, J16.

\section{Introduction}

Since Mitchell's (1927) pioneering study of business cycles, followed by Keynes' General Theory (1936), the literature has assumed that key economic variables exhibit asymmetric behavior over the course of the business cycle, with a dynamic relationship between business cycle fluctuations and unemployment. In a recent study, Belaire-Franch and Peiró (2015) examine the relationship between unemployment and business cycles in the UK and

\footnotetext{
* Department of Economics, Shaheed Zulfikar Ali Bhutto Institute of Science and Technology, Karachi, Pakistan.

** Monetary Policy Department, State Bank of Pakistan, Karachi, Pakistan.
} 
US. They find an unconditional asymmetry in both countries' employment rate. In the US, cyclical contractions have a far stronger effect on unemployment than expansions. However, in the UK, male unemployment is more sensitive to cyclical changes than female employment. Several other studies have investigated the asymmetry and nonlinearity of the relationship between unemployment and cyclical movements from the perspective of Okun's law: see, for example, Huang and Chang (2005), Silvapulle, Moosa and Silvapulle (2004), Virén (2001) and Cuaresma (2003).

In the field of labor economics, it is well established that aggregate supply is only slightly pro-cyclical (Mincer, 1966; Pencavel, 1986; Killingsworth \& Heckman, 1986; Heckman, 1993). Consequently, macroeconomists have focused on unemployment as a business cycle indicator while abstracting from labor force participation. The literature on monetary policy and simple rules assume that the unemployment gap and output gap are roughly equal (Erceg \& Levin, 2014). Blagrave and Santoro (2017) find that age plays an important role in determining participation decisions, especially among men. They explain how the labor participation decision is based on age cohort and business cycle effects. Using a cohortbased analysis, their projected participation rates suggest that population aging may put downward pressure on labor supply and, therefore, on potential output. The study recommends policy measures to increase female labor force participation to compensate for the downward demographic pressure.

This study takes into account previous findings and labor market developments over recession and boom periods in Pakistan. Figures 1 and 2 illustrate labor force participation trends by gender as well as the role of age in determining labor force participation. Movements in female labor force participation are more sensitive to age than male labor force participation.

Figure 1: Trends in male labor force participation

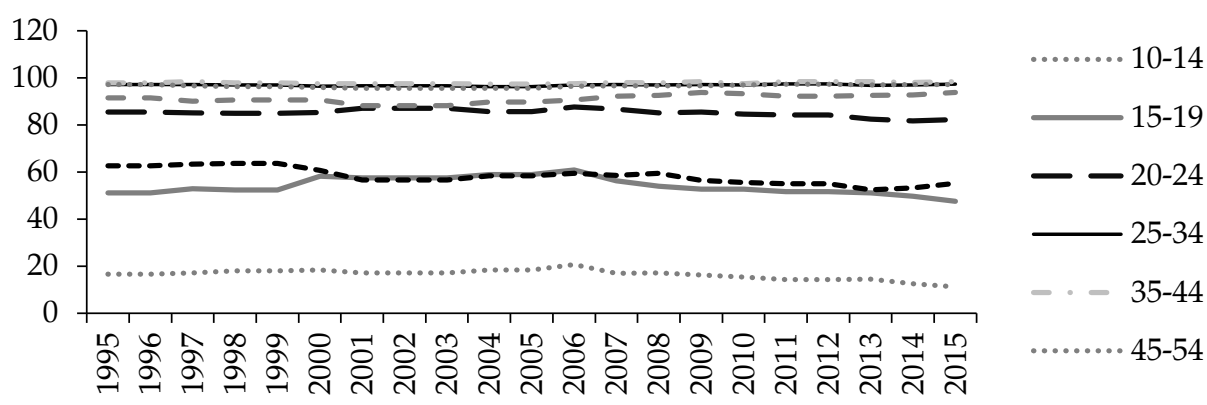

Source: Pakistan Economic Survey (2015-16) 


\section{Figure 2: Trends in female labor force participation}

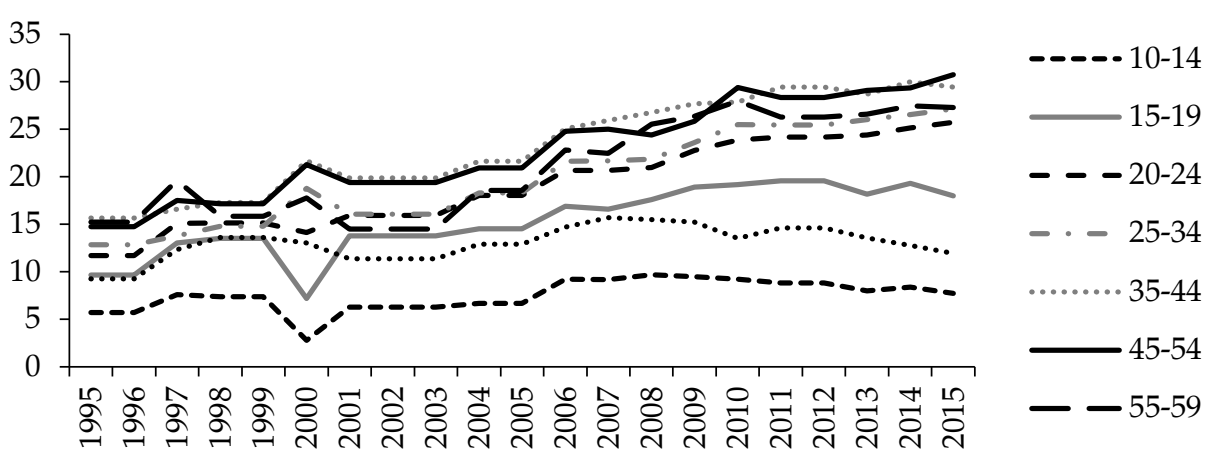

Source: Pakistan Economic Survey (2015-16)

Many studies argue that cyclical movements in the hourly earnings ratio are due to changes in the characteristics of workers in each group or to changes in pure wage discrimination over the cycle (Figure 3). Biddle and Hamermesh (2013) relate the composition effect to the greater vulnerability of women and minorities to cycle-related job loss. They find that women are more likely to be employed in relatively stable, albeit lower-paid industries and that their relative earnings are hurt by negative shocks.

\section{Figure 3: Labor market developments}

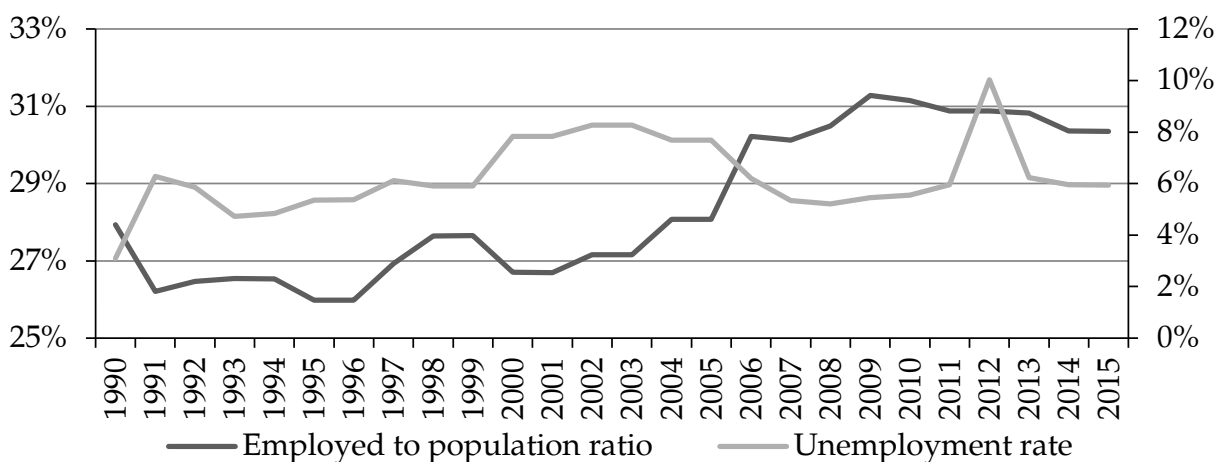

Source: Pakistan Economic Survey (2015-16)

Glewwe and Hall (1998) identify which socioeconomic groups are most vulnerable to macroeconomic shocks, based on panel data from Peru. Their findings suggest that households headed by women and those with better-educated heads are less vulnerable, while households with more children are more vulnerable. Their study finds that government transfer networks are unable to protect the poor during major macroeconomic shocks. 
Broadly, there are two types of vulnerability: (i) policy-induced (in response to changes in government policies) and (ii) market-induced (in response to a macroeconomic shocks). That certain groups are unable to adapt to business cycle shocks reflects market forces interact with household characteristics and earning ability in a rapidly changing environment. For example, older individuals have less incentive to learn new skills and, therefore, their income may decline by more than average after a business cycle shock.

We focus on market-induced vulnerability, as measured by changes in the earnings of individuals over the business cycle. The analysis is disaggregated by gender and employment type. We categorize historical trends in real economic growth as recession, trough, expansion and boom periods by applying the Hodrick-Prescott (HP) filter. Changes in the real earnings (representing a macroeconomic shock) of various socioeconomic groups are determined during growth transition periods (from boom to trough and trough to boom). The study tests the hypothesis that growth shocks during an economic downturn have an adverse impact on lowerincome groups, while expansions tends to benefit higher-income groups.

\section{Business Cycle Fluctuations}

The short-term cyclical movements and long-term trajectory of macroeconomic indicators provide valuable information on recession and boom phases. Our objective is to investigate the impact of macroeconomic changes on the real earnings of various socioeconomic groups. Therefore, short-term cyclical movements are filtered out from real economic growth and inflation using the HP method (Figure 4). This enables us to identify the country's economic conditions over time.

Figure 4: HP filter trends in growth and inflation

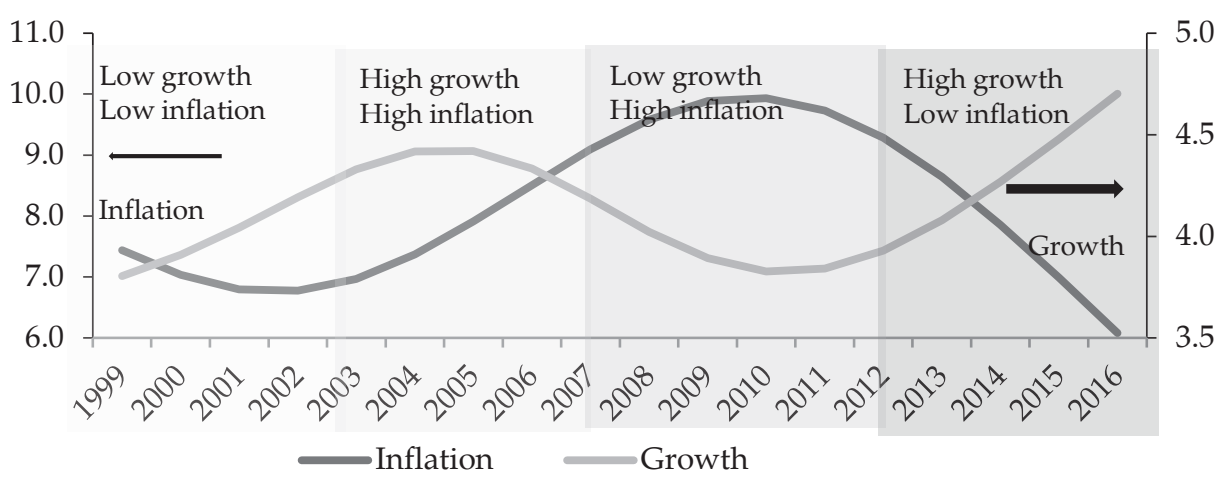

Source: Pakistan Economic Survey (2015-16) 
Pakistan's economy witnessed low real economic growth and low inflation (pure recession) during the FY1999-FY2003 period, and high growth and high inflation during the FY2003-FY2007 period. Following oil price shocks and the global financial crisis, inflation continued to rise while real economic growth plunged in the FY2008-FY2012 period. Decreasing international commodity prices and prudent fiscal and monetary management led to historically low levels of inflation, while real economic growth started to improve during the FY2013-FY2016 period.

Our objective is to investigate the impact of these macroeconomic developments on different socioeconomic groups, particularly in relation to the labor market. District-level data from the Pakistan Social and Living Standards Measurement (PSLM) Survey for 2004/05, 2006/07, 2008/09, $2012 / 13$ and 2014/15 is used to compute the various indicators of earner groups. The consumer price index (CPI) is used to convert the data into real terms. Average real earnings were PKR 5,896 in 2005 and increased to PKR 6,472 and PKR 6,623 in 2007 and 2009, respectively. In 2015, earnings fell to PKR 5,708 from PKR 6,598 in 2013. Real earnings improved as the economy recovered from a recession in the mid-2000s, but shrank during the recession of 2008-10.

These patterns indicate that movements in the business cycle pass through into earnings, which may be due to consistent changes in wages and earning opportunities. The purpose of this study is to investigate the implications of economic fluctuations for various earner groups and determine which groups have benefitted most during boom periods and which have suffered most during recessions.

Kernel density plots of real earnings (in logarithmic form) are presented in Figure 5. These indicate that the median is lower and dispersion higher for women than for men. The distribution of men's real earrings shift to the right, which implies that the gains of the recovery period during 200407 benefitted male workers more than female workers. However, the situation was reversed during the recession of 2008: we see a significant leftward shift in the distribution of women's earnings, while men's earnings do not change that much. These stylized facts capture the varying impact of economic fluctuations across gender. 


\section{Figure 5: Kernel density of real earnings}
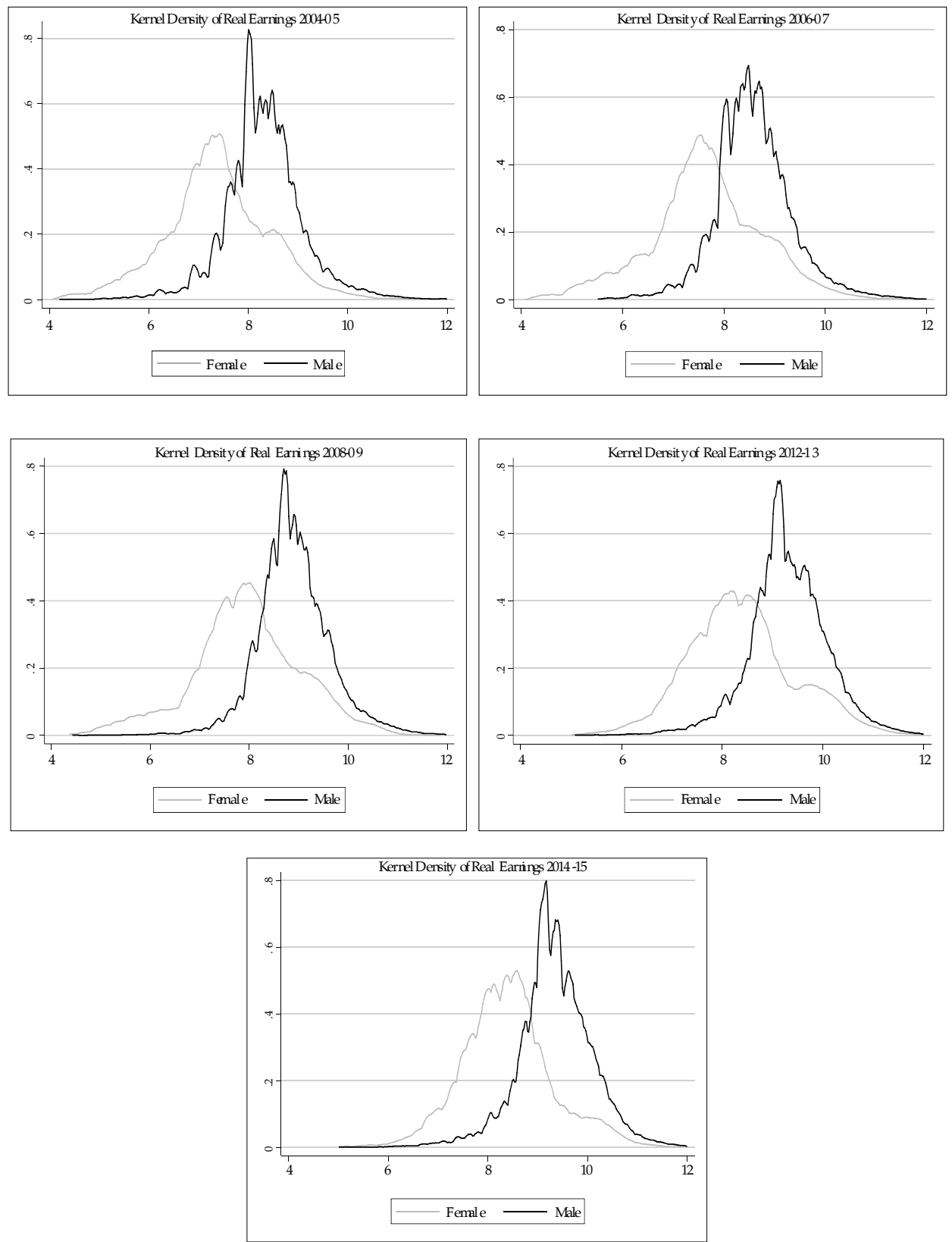

Source: Pakistan Social \& Living Standard Measurement Survey (2004-05, 2006-07, 2008-09, 2012-13 and 2014-15) 


\section{Methodology}

We use two methods to investigate the impact of economic fluctuations. The first method entails calculating the vulnerability index developed by Guillaumont (2009), which measures the extent of changes in the impact of economic growth on real earnings. The second method uses economic activity indicators such as inflation, employment opportunities and regional characteristics to determine real earnings. The generalized method of moments (GMM) is used to resolve any endogeneity and heterogeneity in the data.

\subsection{Vulnerability Index}

Changes in real economic growth affect real earnings differently. When individuals' real earnings are in line with real GDP growth, this is considered 'normal'. Fluctuations in real earnings due to economic changes reflect vulnerability. For instance, if real economic growth slows down from 6 to 2 percent and individuals' real earnings follow a similar pattern, then this is considered normal. However, if individuals' earnings drop by 5 percent, then these individuals are considered to be vulnerable to economic shocks. Using this concept, we calculate the vulnerability index for different earner groups in Pakistan.

Real earnings are calculated by deflating nominal earnings with the price index:

$$
y_{i, t}=\frac{Y_{i, t}}{P I} * 100
$$

$y_{i, t}$ denotes the real earnings of an individual at time $t, Y_{i, t}$ denotes the nominal earnings of an individual at time $t$ and $P I$ is the price index.

Next, the data is sorted by income group - lower, lower middle, middle, upper middle and higher - based on the real earnings of each individual. The lower-income group includes individuals who earn less than the 10th percentile of total earners. The lower middle-income group comprises the 25 th percentile. The middle-income group includes median earners. The 75th percentile represents the upper middle-income group and the 90th percentile comprises the upper-income group. Following this classification, individuals are sorted by gender, location, demographics, education and employment type.

Real earnings are standardized and converted into Z scores: 


$$
Z=\frac{X-\mu}{\sigma}
$$

$X$ denotes the real earnings of individual $i$ in a specific group, $\mu$ is real GDP growth and $\sigma$ is the standard deviation of the individual's real earnings:

$$
f(X)=\frac{e^{-(X-\mu)^{2} / 2 \sigma^{2}}}{\sigma \sqrt{2 \pi}}
$$

Under the standardizing process, the standard deviation $(\sigma)$ becomes unity. Therefore, the probability density function becomes:

$$
f(X)=\frac{e^{-(X-\mu)^{2} / 2}}{\sqrt{2 \pi}}
$$

This function captures the probability that the individual's earnings correspond to real GDP growth. The probability takes a minimum value close to 0 and a maximum value close to 1 . The vulnerability index is derived by multiplying these probabilities by 100. An index value of 0 indicates that the individual's earnings correspond to aggregate economic growth. An index value of 100 represents the maximum diversion of the individual's earnings from aggregate economic growth.

\subsection{Model Specification and Estimation}

To gauge the impact of aggregate fluctuations on various groups, we determine their real earnings based on macroeconomic indicators and group-specific socioeconomic indicators. The real earnings of a given group are specified by a set of explanatory variables as follows:

$$
\bar{y}_{j, t}=f\left(Z_{1}, Z_{2}\right)
$$

where $\bar{y}_{j, t}=\frac{1}{\mathrm{~N}} \sum_{\mathrm{i}=1}^{\mathrm{N}} y_{i, t} \cdot \bar{y}_{j, t}$ denotes the average earnings of group $j, Z_{1}$ is the vector of endogenous covariates and $Z_{2}$ is the vector of exogenous variables. The endogeneity of the specification and the heterogeneity of the groups means we must employ GMM (Hansen, 1982) to obtain consistent and efficient estimates. Using the appropriate instrumental variables, GMM is applied to resolve the endogeneity of the aggregated price data for each city.

The vector of endogenous covariates includes employed labor and inflation. Employed labor is an indicator of economic opportunity and, therefore, represents economic growth. The variable is instrumented by 
inflation in the previous period, unemployment and the fraction of married persons in the district. Nonfood inflation is considered endogenous to the system and is instrumented by its previous values. Food inflation is determined by seasonal factors and considered an included instrument. Given the lack of information on other aspects of this variable, we assume that food inflation is exogenous because it may lead to under-identification. The fraction of rural areas in the district are exogenous. The final model is:

$$
\begin{aligned}
& Y_{i, t}=\alpha_{i}+\beta_{1}\left(\hat{g}_{i, t}\right)+\beta_{2}\left(\hat{\pi}_{i, t}^{n f}\right)+\beta_{2}\left(\pi_{i, t}^{f}\right)+\gamma\left(R_{i, t}\right)+\epsilon_{i, t} \\
& g_{i}=f\left(\pi_{i, t-1}, U_{i, t}, M_{i, t}\right) \text { and } \pi_{i, t}^{n f}=f\left(\pi_{i, t-1}^{n f}\right)
\end{aligned}
$$

where $\alpha_{i}=$ fixed effects, $t=$ time in years, $i=$ district, $Y_{i, t}=$ real earnings (of a specific group), $g_{i t}=$ employed labor force, $\pi_{i, t}^{n f}=$ nonfood inflation, $\pi_{i, t}^{f}$ $=$ food inflation, $R_{i, t}=$ fraction of rural areas in the district, $U_{i, t}=$ unemployment rate prevailing in the region and $M_{i, t}=$ fraction of married persons in the district. Here, $Y_{i, t}$ (real earnings) is the dependent variable, $g_{i t}$ and $\pi_{i, t}^{n f}$ are endogenous covariates, $\pi_{i, t}^{f}$ and $R_{i, t}$ are the included instruments, and $U_{i, t}$ and $M_{i, t}$ are excluded instruments.

\section{Data and Variables}

This study requires household-level data on employed labor, its demographics and its earning capacity. We employ district-level data from the PSLM Survey for 2004/05, 2006/07, 2008/09, 2012/13 and 2014/15, which provides information on the working-age population, employed labor and household earnings. The Pakistan Economic Survey provides data on overall consumer prices and food and nonfood prices at the district level. The PSLM indicators are aggregated at the district level, enabling us to measure the employed labor force, the fraction of rural areas in the district and the fraction of married persons in the district.

Since the district is our basic unit of analysis, we construct income distribution parameters from the PSLM data at this level. These indicators are disaggregated by gender and earning percentiles within a district (see Section 3.1). The district-level CPI is then used to convert earnings into real terms. Finally, real earnings are converted to standardized $\mathrm{Z}$ scores. The probability density of each $\mathrm{Z}$ score variable is computed and multiplied by 100 to construct the vulnerability index. An index value close to 0 means that the change in real earnings of specific individuals is equal to aggregate economic growth. An index value close to 100 indicates maximum vulnerability. 
Given the lack of consistent time-series data, we can determine only five observations for each variable computed from the PSLM data. However, a consistent inflation time-series is available. The vulnerability of lowerincome groups is also measured with respect to changes in inflation over time. The availability of city-level data on inflation allows us to examine vulnerability across districts, while the panel data on inflation and economic growth enables us to investigate the implications of the tradeoff between economic activity and inflation for vulnerable groups.

\section{Results}

Gauging the extent to which macroeconomic fluctuations affect different socioeconomic groups helps identify which of them is most vulnerable. This is measured by the change in real earnings during the recovery and boom phases of the business cycle and vice versa.

We start by measuring the impact of business cycle fluctuations on the real earnings of male and female workers. To gauge the impact of aggregate economic fluctuations on income distribution, each subgroup is categorized by real earnings (lower-income, lower middle-income, middleincome, upper middle-income and high-income) and each earner group by gender, province, employment type, age cohort and education level. This leads to the division of all earning persons into 330 groups. The vulnerability index is calculated for each category: the extent of vulnerability of each group is given by income group and over time. A stochastic analysis using GMM is carried out to estimate the impact of inflation and economic activity on the real earnings of each group.

Table 1 reports the percentage difference in the vulnerability index for female and male workers. Overall, the results indicate that employed women are 63.3 percent more vulnerable to economic shocks than men. Differences in the extent of vulnerability by income class vary: for instance, middle-income female workers are 151 percent more vulnerable to economic shocks than their male counterparts. 
Table 1: Percentage difference in female versus male vulnerability

\begin{tabular}{|c|c|c|c|c|c|c|}
\hline \multirow[b]{2}{*}{ Variable } & \multicolumn{6}{|c|}{ Earner groups } \\
\hline & $\mathbf{L}$ & LM & $\mathbf{M}$ & UM & $\mathbf{H}$ & Overall \\
\hline \multicolumn{7}{|l|}{ Location } \\
\hline Pakistan & 40 & 52 & 151 & 20 & 90 & 63.3 \\
\hline Punjab & 48 & 99 & 161 & 170 & 114 & 111.1 \\
\hline Sindh & 124 & 231 & 252 & 72 & 123 & 134.4 \\
\hline $\mathrm{KP}$ & 171 & 21 & 64 & 101 & 41 & 70.7 \\
\hline Balochistan & 428 & 299 & 222 & 115 & 69 & 224.1 \\
\hline \multicolumn{7}{|l|}{ Employment type } \\
\hline Employer & 160 & 44 & 44 & -11 & -16 & 20.2 \\
\hline $\begin{array}{l}\text { Self-employed } \\
\text { (nonagriculture) }\end{array}$ & 86 & 144 & 135 & -10 & 51 & 76.9 \\
\hline Paid employee & -7 & 67 & 59 & 45 & 79 & 48.7 \\
\hline Self-employed (agriculture) & 198 & -29 & 15 & 68 & 63 & 35.2 \\
\hline \multicolumn{7}{|l|}{ Age } \\
\hline Age cohort 10-19 & 141 & -17 & 19 & -7 & 43 & 38.7 \\
\hline Age cohort 20-29 & 67 & 27 & 144 & 114 & 53 & 74.8 \\
\hline Age cohort 30-39 & 64 & 8 & -13 & 106 & 89 & 54.1 \\
\hline Age cohort 40-49 & 3 & -26 & 16 & 60 & 147 & 42.2 \\
\hline Age cohort 50-59 & 110 & 14 & 17 & 45 & 177 & 71.5 \\
\hline Age cohort 60 and above & 3 & 9 & 41 & 71 & 24 & 25.1 \\
\hline \multicolumn{7}{|l|}{ Education } \\
\hline Illiterate & 88 & 88 & 21 & -33 & -50 & 24.7 \\
\hline Primary & 89 & 148 & 140 & 85 & 186 & 116.7 \\
\hline Secondary & 214 & 173 & 82 & -10 & 168 & 132.1 \\
\hline Matric & 39 & 63 & 479 & 36 & 88 & 99.8 \\
\hline FA & 4 & -22 & 58 & -37 & -58 & -12.0 \\
\hline BA & 42 & 23 & 52 & 28 & 6 & 30.0 \\
\hline Professional & 94 & 54 & -8 & 30 & 41 & 38.6 \\
\hline
\end{tabular}

Note: $\mathrm{L}=$ lower-income, $\mathrm{LM}=$ lower middle-income, $\mathrm{M}=$ middle-income, $\mathrm{UM}=$ upper middle-income, $\mathrm{H}=$ higher-income.

Source: Authors' calculations based on data from the PSLM Survey.

A significant degree of gender discrimination emerges from this analysis. Clearly, certain socioeconomic groups face greater fluctuations in income due to business cycle movements. The aggregate analysis suggests there is no significant difference among the provinces in terms of the extent of vulnerability. However, female workers in Balochistan are highly vulnerable to shocks compared to male workers, while female workers in $\mathrm{KP}$ are less vulnerable than their counterparts in the other provinces. 
Barring employers, there is no significant difference in vulnerability among employment categories - employers are highly vulnerable to economic growth shocks. A closer analysis reveals that female workers are more vulnerable than male workers across all employment categories. The largest differences occur among self-employed persons in the nonagriculture category. However, higher-income female employers are less vulnerable to economic shocks than their male counterparts.

Both younger as well as older age cohorts are more vulnerable than the age cohorts in between, although this decreases in the case of workers who have completed secondary school or matriculation. Among paid employees, teenage workers and those above 60 are more vulnerable to economic shocks. Female workers in their 20s and 50s are more vulnerable than their male counterparts in other age categories. The vulnerability index is highest for graduates and lowest for earners who have finished secondary school and matriculation. Among those with an intermediate degree, male workers are more vulnerable than female workers. While higher-income female workers with no education are not vulnerable to economic shocks, female workers who have completed primary and secondary school and matriculation are highly vulnerable relative to their male counterparts.

The extent of vulnerability across earner groups over time indicates that vulnerability was highest during 2006/07. It fell by almost 60 percent in 2008-09 and then increased by 80 percent in 2012/13. This was followed by a slight decline of 10 percent in 2014/15. Since these indices are based on real earnings, they can be examined in terms of real growth. The increase in economic growth during 2002 to 2007 enhances the variability of real earnings. Both genders have similar patterns of vulnerability to economic growth shocks. The extent of vulnerability is higher in Punjab and KP than elsewhere. Barring employers (whose vulnerability increases over time), all employment categories face the same extent of vulnerability as a whole. In terms of age cohort, vulnerability to economic shocks decreases across all categories except workers over 60 . Highly educated workers become more vulnerable over time.

The asymmetric impact of business cycle fluctuations is determined by looking at changes in the vulnerability index over time. In the case of both genders, the results indicate that three categories - workers in Balochistan, employers and workers with a graduate degree - are more sensitive to shocks during a recession than during recovery and booms. These effects are more pronounced among female workers. Barring those in KP, female earners in all the provinces, employers, the self-employed in nonagriculture 
sectors and those with an intermediate or graduate degree are more vulnerable during a downturn and benefit less during recovery and booms than their male counterparts. There is no evidence of the asymmetric impact of economic growth among different age cohorts.

The index-based analysis indicates that, overall, female workers are the most vulnerable. New labor force entrants and older workers about to retire are also more vulnerable to economic shocks. Less-educated female workers are less vulnerable to economic shocks, while those with a graduate degree and above are more vulnerable. See Tables A1-A8 in the Appendix for the indices computed for each socioeconomic group.

Following the deterministic analysis, we compute real earnings by employed labor, food inflation, nonfood inflation and the percentage of rural areas in the district. Given the endogeneity of the employed labor variable as an indicator of economic activity in the district, we use the lagged values of unemployment and inflation as instruments. The GMM results of all 66 equations are reported in Tables A9-A13 in the Appendix. The validity of over-identifying restrictions is tested by the Sargan J statistic. The goodness of fit is indicated by the adjusted R-squared term and the F statistic represents overall significance. The results indicate that almost all the equations satisfy the necessary diagnostics.

Employed labor is positively correlated with real earnings, food inflation has a negative impact on real earnings and nonfood inflation increases real earnings. Moreover, real earnings are higher in rural areas than in urban areas. The magnitude of the coefficients of employed labor, food inflation and nonfood inflation are higher for female workers, which indicates that they are more vulnerable to economic growth and inflation shocks than male workers. The coefficient of economic activity for female workers is 64 percent higher than for male workers, which is consistent with the findings of the simple index analysis. The magnitude of economic activity is higher for Punjab and Balochistan than for the other two provinces. Female workers in Sindh are more sensitive to economic fluctuations than their counterparts elsewhere.

In terms of employment type, the results confirm that employers are more sensitive to economic shocks. However, female workers who are self-employed in agriculture are less sensitive to economic shocks than male workers. The sensitivity of real earnings with employment opportunities increases with the level of education. The impact of food inflation on real earnings falls with the level of education, while nonfood inflation has the opposite effect. The coefficient of employed labor (the 
impact of economic opportunity) is higher for older age cohorts. The impact of food and nonfood inflation is greater among older age cohorts. Finally, the estimates suggest that female workers are more vulnerable to economic fluctuations than male workers.

\section{Conclusion and Policy Recommendations}

Our findings suggest that the extent to which aggregate economic fluctuations pass through to vulnerable segments is important. Further, those groups that suffer most during a recession or slowdown do not necessarily benefit during a recovery or boom. For both genders, the most vulnerable groups include earners in Balochistan. Generally, the most vulnerable groups tend to be female, especially self-employed women in agriculture and female employers. Female earners with an intermediate or graduate degree are also among the most vulnerable, as are graduate male earners. Among male earners overall, those in Balochistan are the most vulnerable.

In terms of income group, high-income female workers are more vulnerable than lower-income female workers in Sindh. Moreover, higherincome paid female employees are more vulnerable than lower-income earners in the same category. The age cohort analysis suggests that young, lower-income female workers are more vulnerable than their older counterparts.

Tackling such variations in vulnerability to economic shocks will require financial innovations in the transfer payment system. An innovative support program that targets the most vulnerable households during a downturn will not only reduce the welfare losses accruing to this segment, but also help increase their consumption, in turn enabling the economy to climb out of the recession. A platform such as the Benazir Income Support Program may be best suited to addressing vulnerability. 


\section{References}

Belaire-Franch, J., \& Peiró, A. (2015). Asymmetry in the relationship between unemployment and the business cycle. Empirical Economics, 48(2), 683-697.

Biddle, J. E., \& Hamermesh, D. S. (2013). Wage discrimination over the business cycle. IZA Journal of Labor Policy, 2(7), 1-19.

Blagrave, P., \& Santoro, M. (2017). Labor force participation in Chile: Recent trends, drivers and prospects (Working Paper No. 17/54). Washington, DC: International Monetary Fund.

Cuaresma, J. C. (2003). Okun's law revisited. Oxford Bulletin of Economics and Statistics, 65(4), 439-451.

Erceg, C. J., \& Levin, A. T. (2014). Labor force participation and monetary policy in the wake of the Great Recession. Journal of Money, Credit and Banking, 46(S2), 3-49.

Glewwe, P., \& Hall, G. (1998). Are some groups more vulnerable to macroeconomic shocks than others? Hypothesis tests based on panel data from Peru. Journal of Development Economics, 56(1), 181-206.

Guillaumont, P. (2009). An economic vulnerability index: Its design and use for international development policy. Oxford Development Studies, 37(3), 193-228.

Hansen, L. P. (1982). Large sample properties of generalized method of moments estimators. Econometrica, 50(4), 1029-1054.

Heckman, J. J. (1993). What has been learned about labor supply in the past twenty years? American Economic Review, 83(2), 116-121.

Huang, H.-C., \& Chang, Y.-K. (2005). Investigating Okun's law by the structural break with threshold approach: Evidence from Canada. The Manchester School, 73(5), 599-611.

Keynes, J. M. (1936). The general theory of employment, interest and money. London: Palgrave Macmillan. 
Killingsworth, M. R., \& Heckman, J. J. (1986). Female labor supply: A survey. In O. C. Ashenfelter \& R. Layard (Eds.), Handbook of labor economics (vol. 1, pp. 103-204). Amsterdam: Elsevier.

Mincer, J. (1966). Labor force participation and unemployment: A review of recent evidence. In R. A. Gordon \& M. S. Gordon (Eds.), Prosperity and unemployment (pp. 73-112). New York: Wiley.

Mitchell, W. C. (1927). Business cycles: The problem and its setting. New York: National Bureau of Economic Research.

Pencavel, J. (1986). Labor supply of men: A survey. In O. C. Ashenfelter \& R. Layard (Eds.), Handbook of labor economics (vol. 1, pp. 3-102). Amsterdam: Elsevier.

Silvapulle, P., Moosa, I. A., \& Silvapulle, M. J. (2004). Asymmetry in Okun's law. Canadian Journal of Economics/Revue canadienne d'Economique, 37(2), 353-374.

Virén, M. (2001). The Okun curve is non-linear. Economics Letters, 70(2), 253-257. 

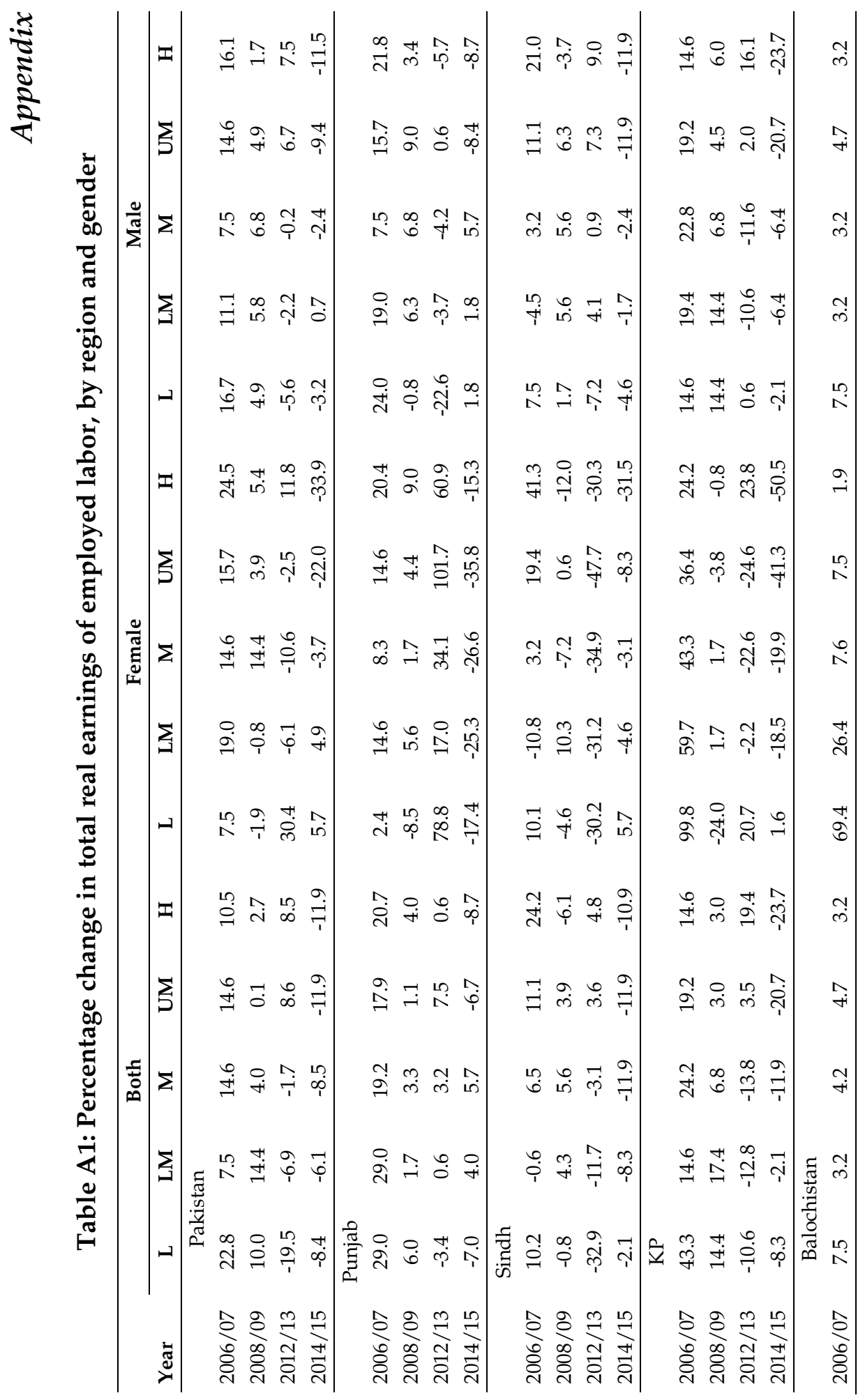


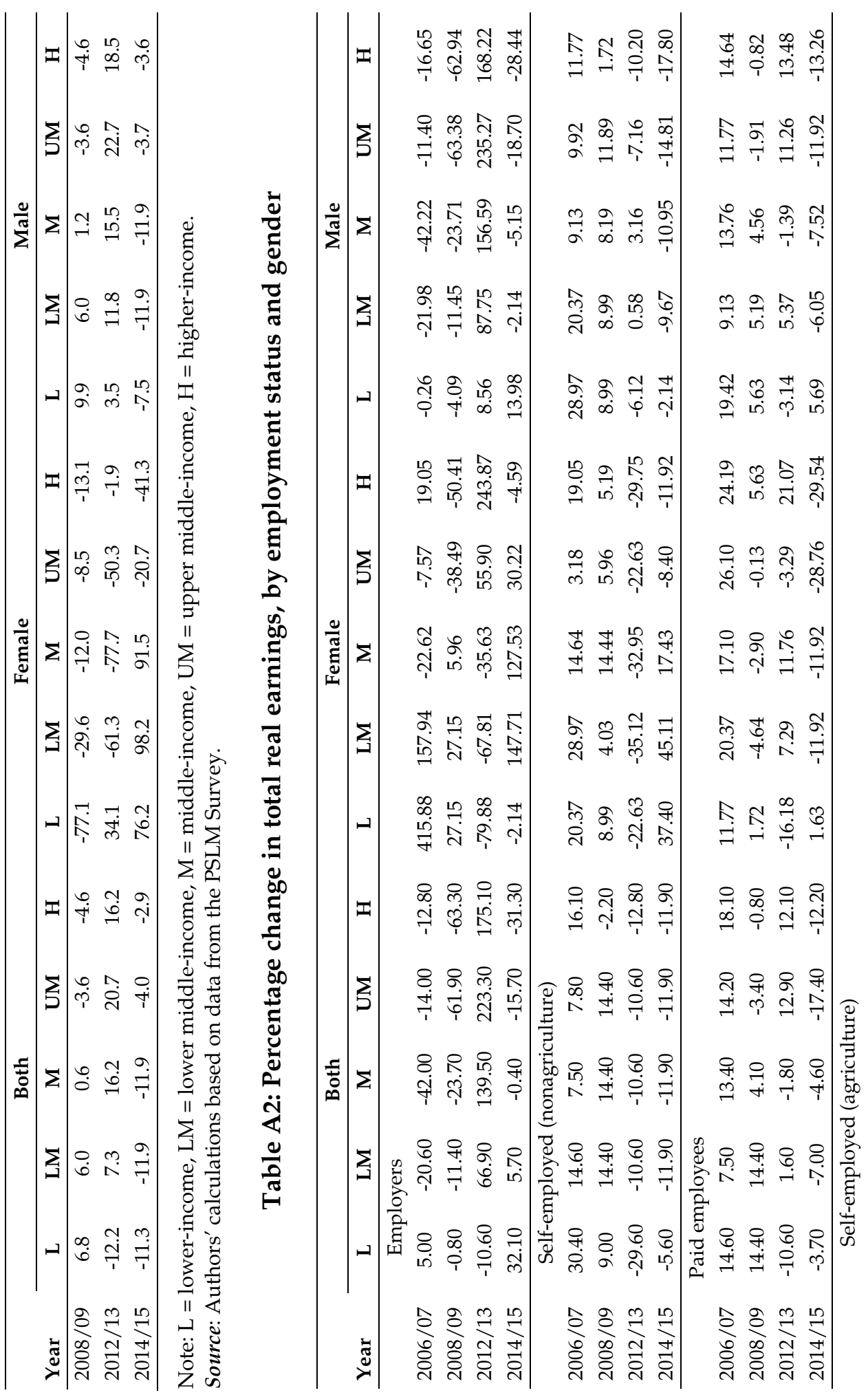




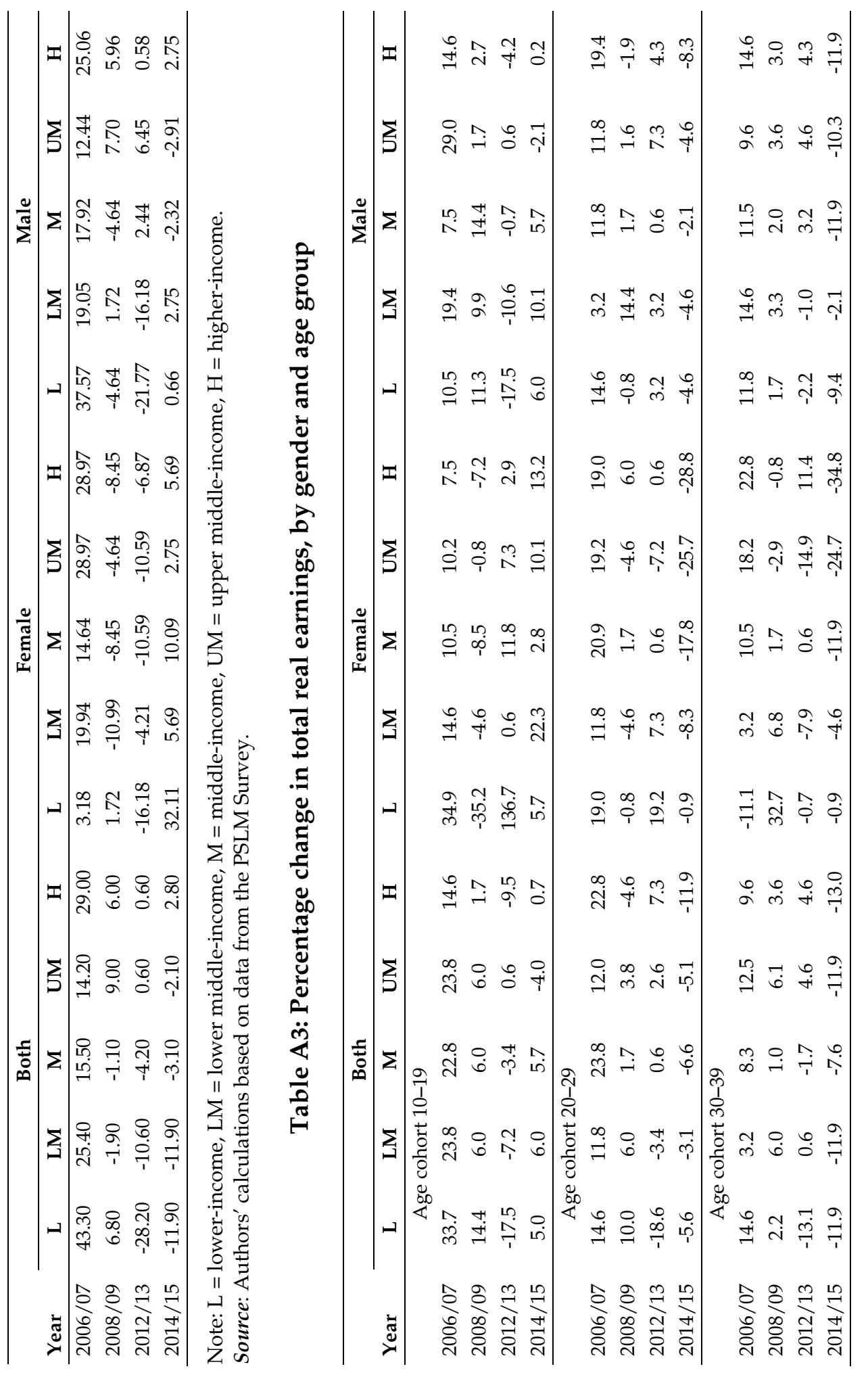




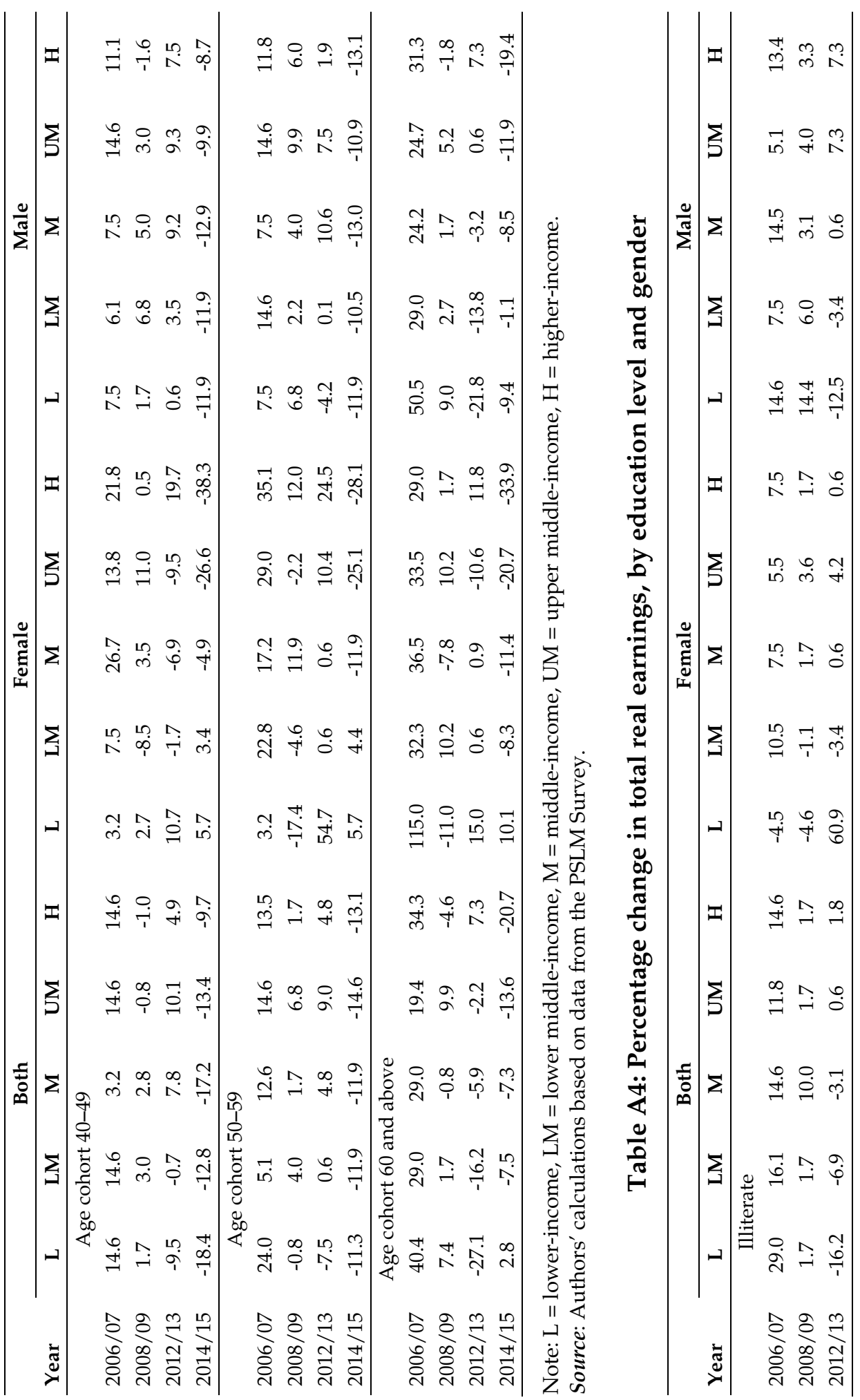




\begin{tabular}{|c|c|c|c|c|c|}
\hline$|\mathbb{I}| \stackrel{10}{i}$ & مُ & 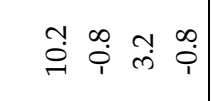 & 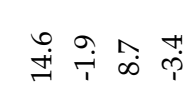 & 있ㅇำ & 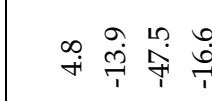 \\
\hline$\vdots$ & 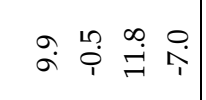 & 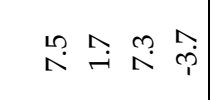 & 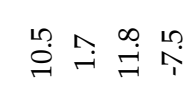 & 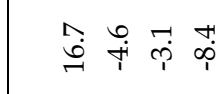 & $\stackrel{+}{9}+\frac{7}{4}$ \\
\hline & 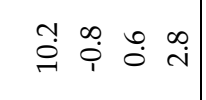 & 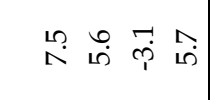 & $\stackrel{\infty}{\exists} \stackrel{\sim}{=}$ & $\stackrel{\circ}{g}$ & $\tilde{\lambda}_{4}^{\infty} \stackrel{\infty}{i}$ \\
\hline$\Sigma$ & 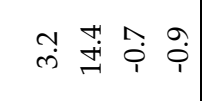 & 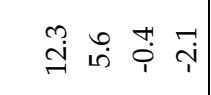 & 웜욤 تُ & 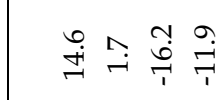 & لُّ \\
\hline 17 & 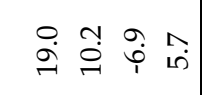 & 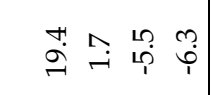 & $\ddot{\dot{d}}$ & 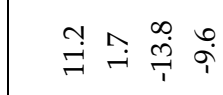 & : \\
\hline is & 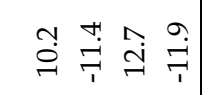 & 过 국 & 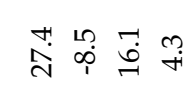 & 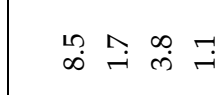 & 걸 \\
\hline & 웜 & 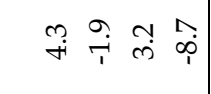 & 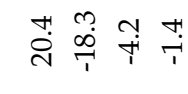 & 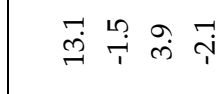 & 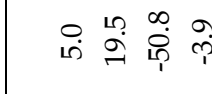 \\
\hline & 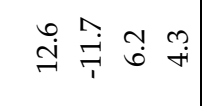 & 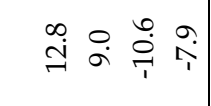 & 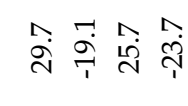 & 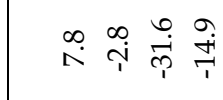 & कृष्त के के \\
\hline & 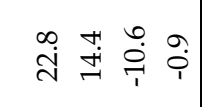 & 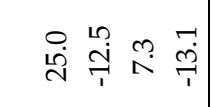 & 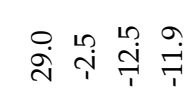 & ن요 & \\
\hline & 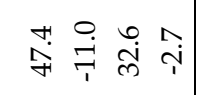 & 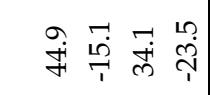 & m) & ભ & . \\
\hline & 氖 & 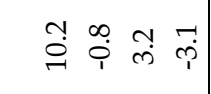 & 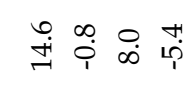 & $\stackrel{\overbrace{}}{\subseteq}$ & ชิ \\
\hline & $\stackrel{+}{\circ}$ & 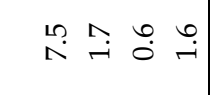 & 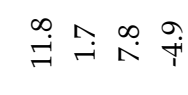 & $\vec{\exists}$ & 12 \\
\hline & 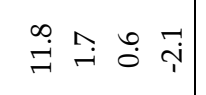 & 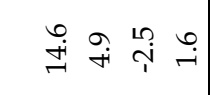 & 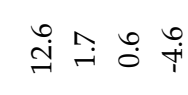 & $\stackrel{+b}{\infty}$ & $\stackrel{\circ}{g}+$ \\
\hline & & 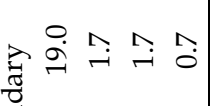 & 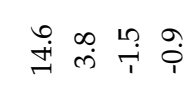 & $\vec{E}$ & $\vec{d} \stackrel{\infty}{i}$ \\
\hline & & & & & 迎 \\
\hline & & & & & \\
\hline
\end{tabular}




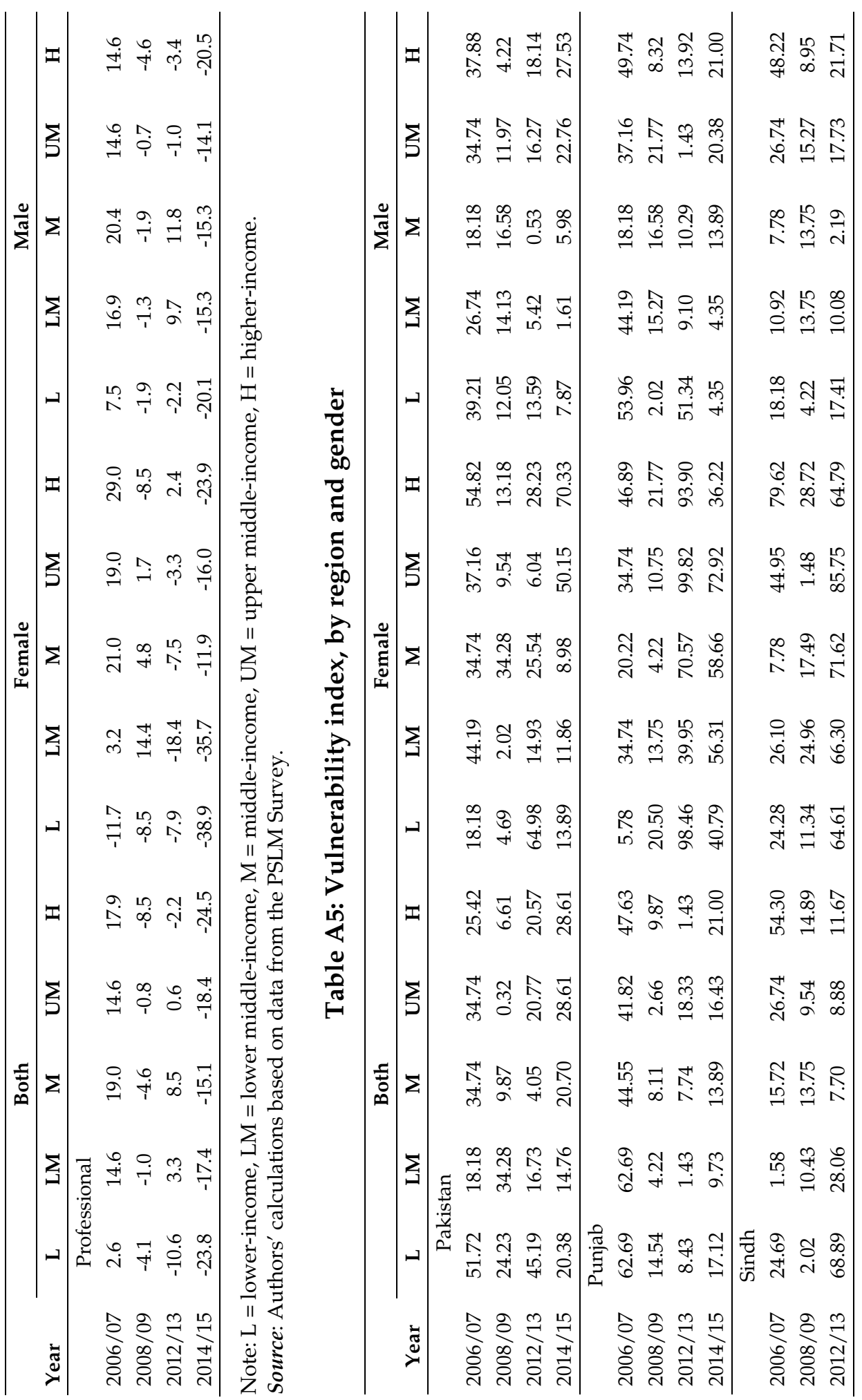




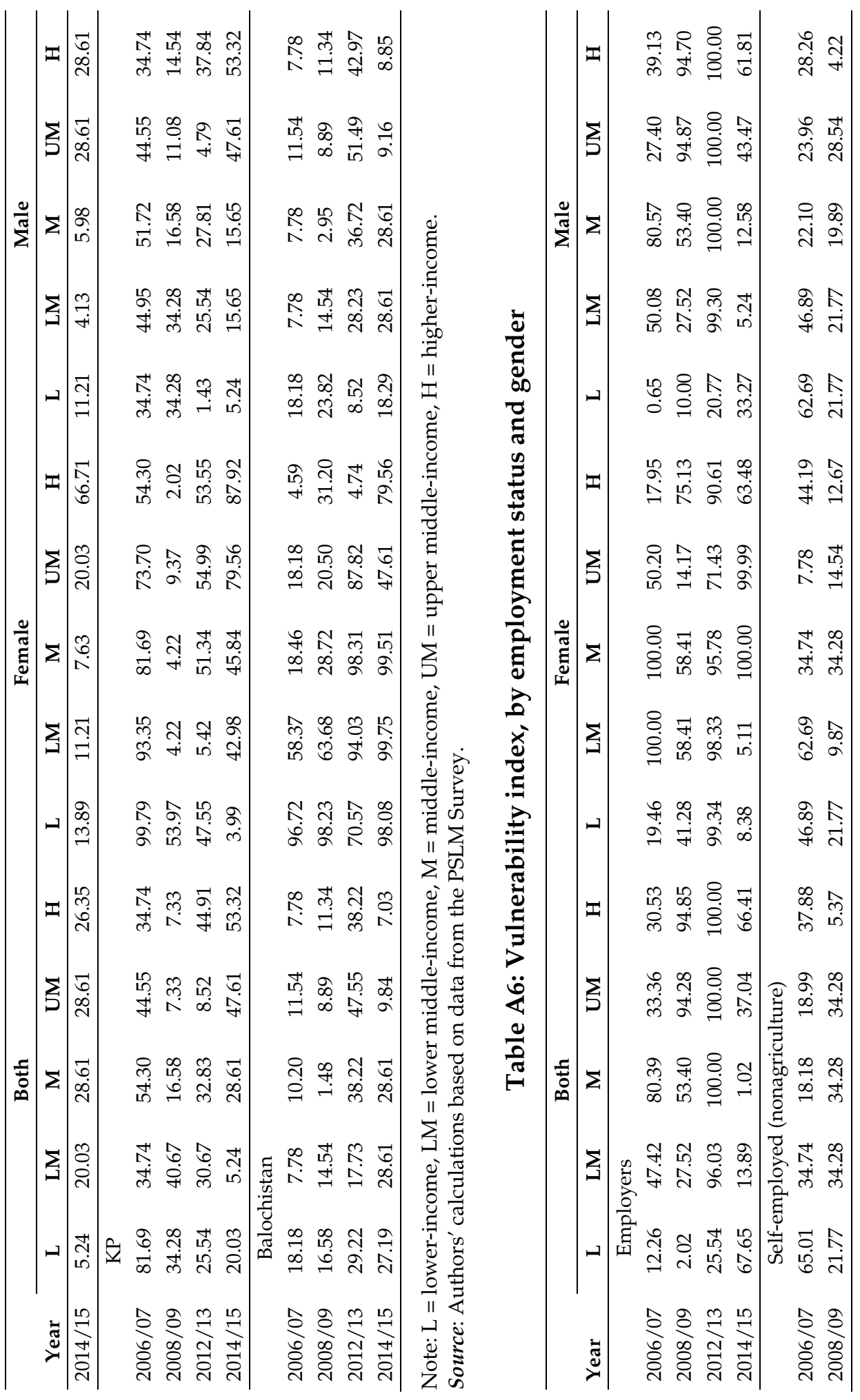




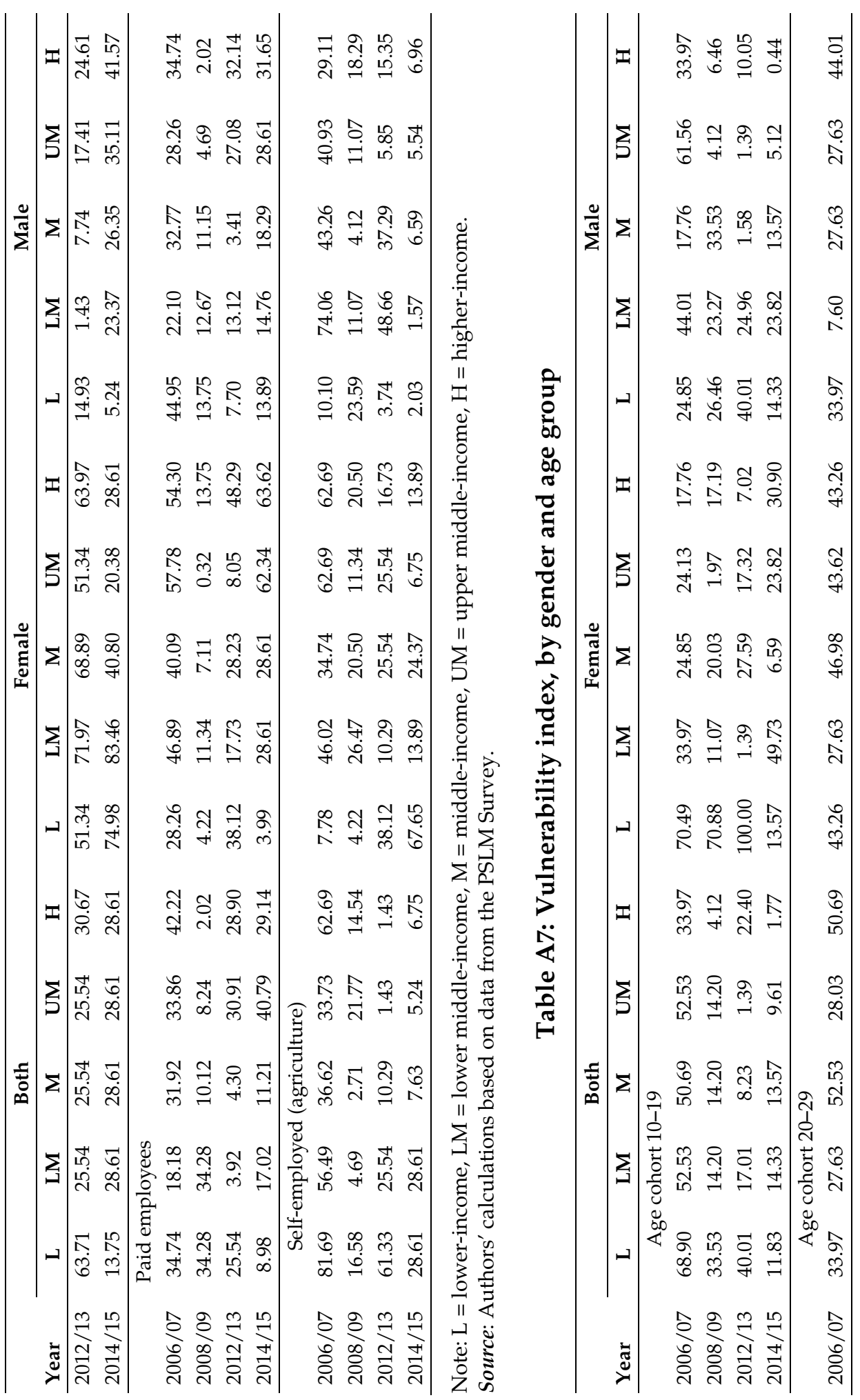




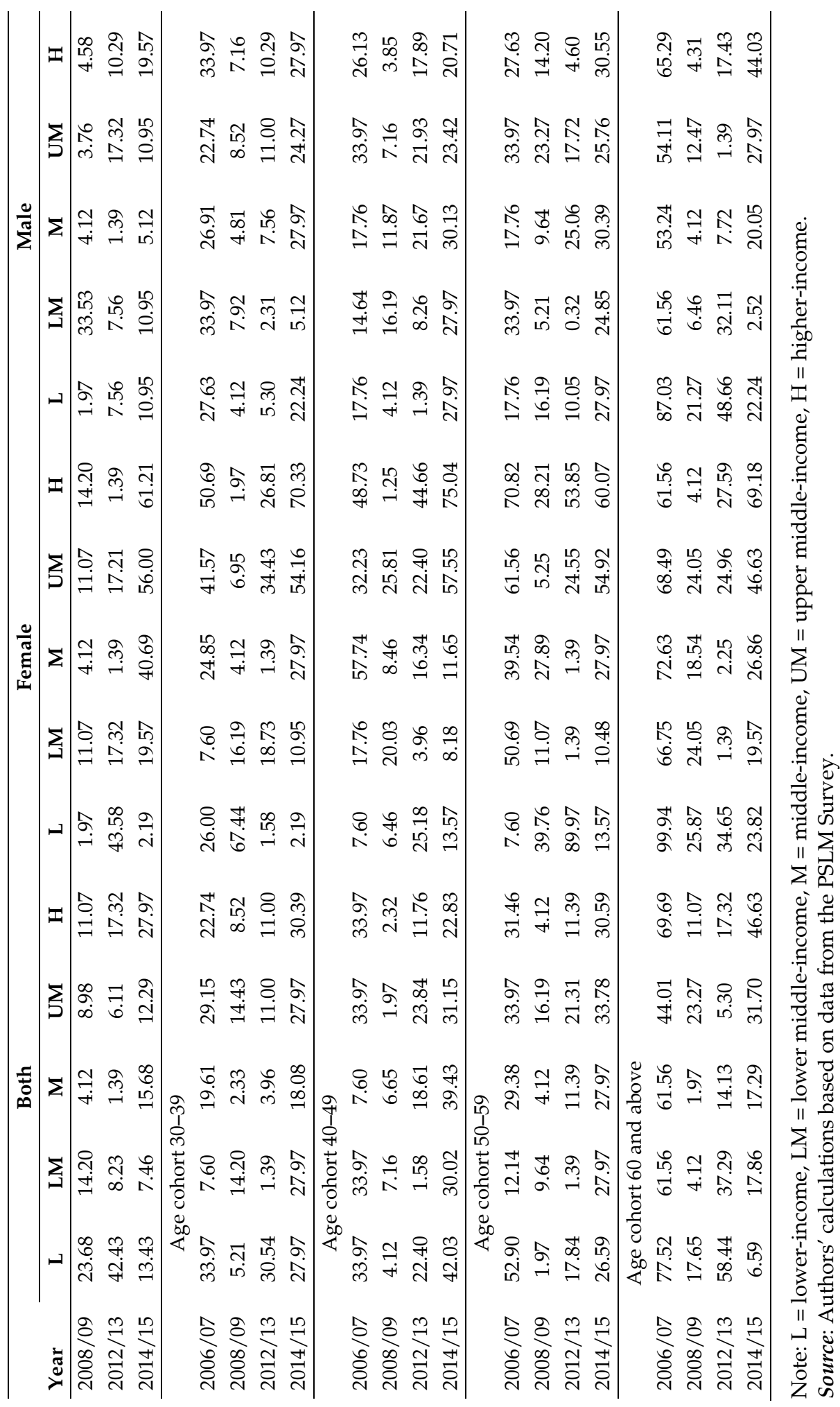




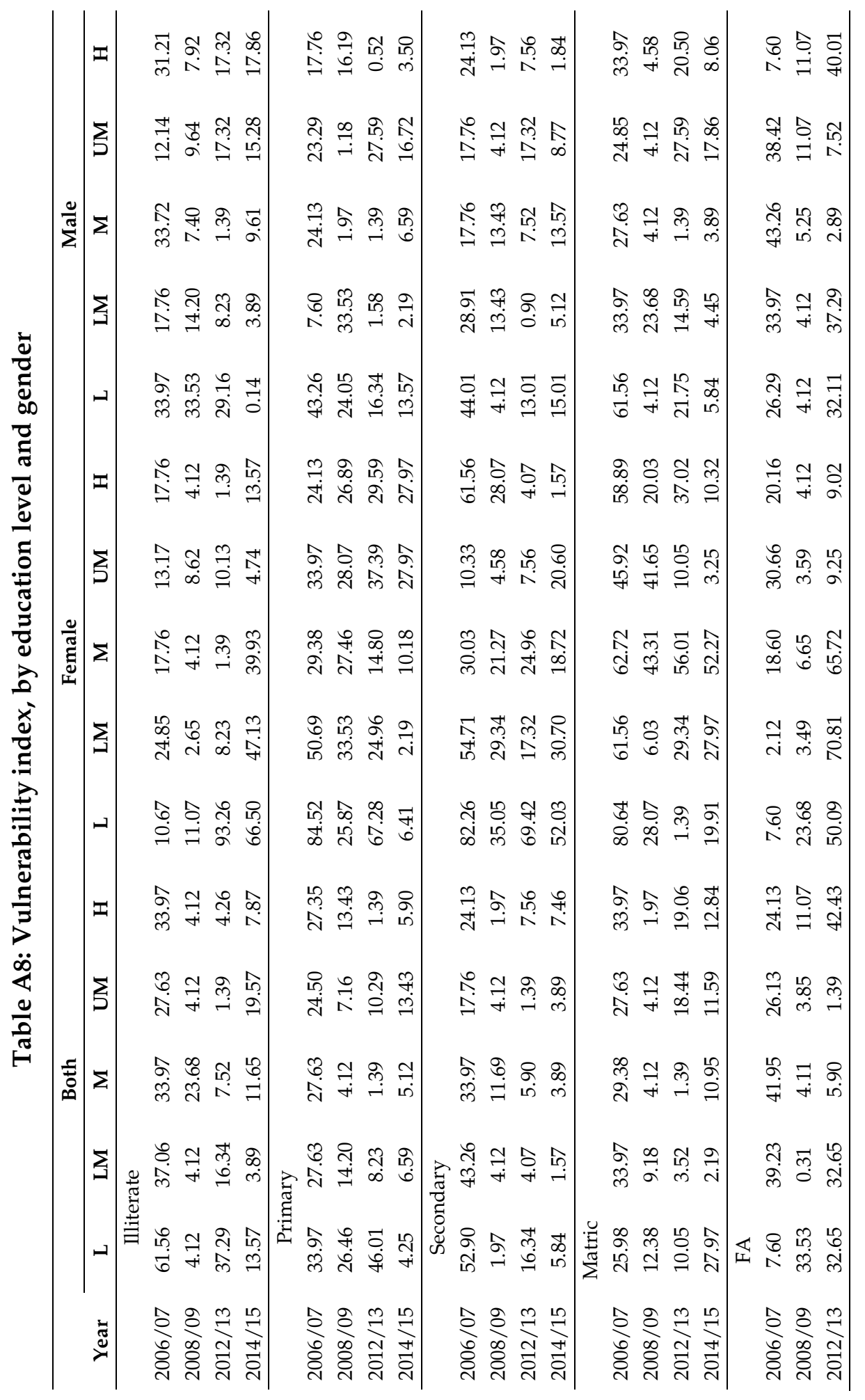




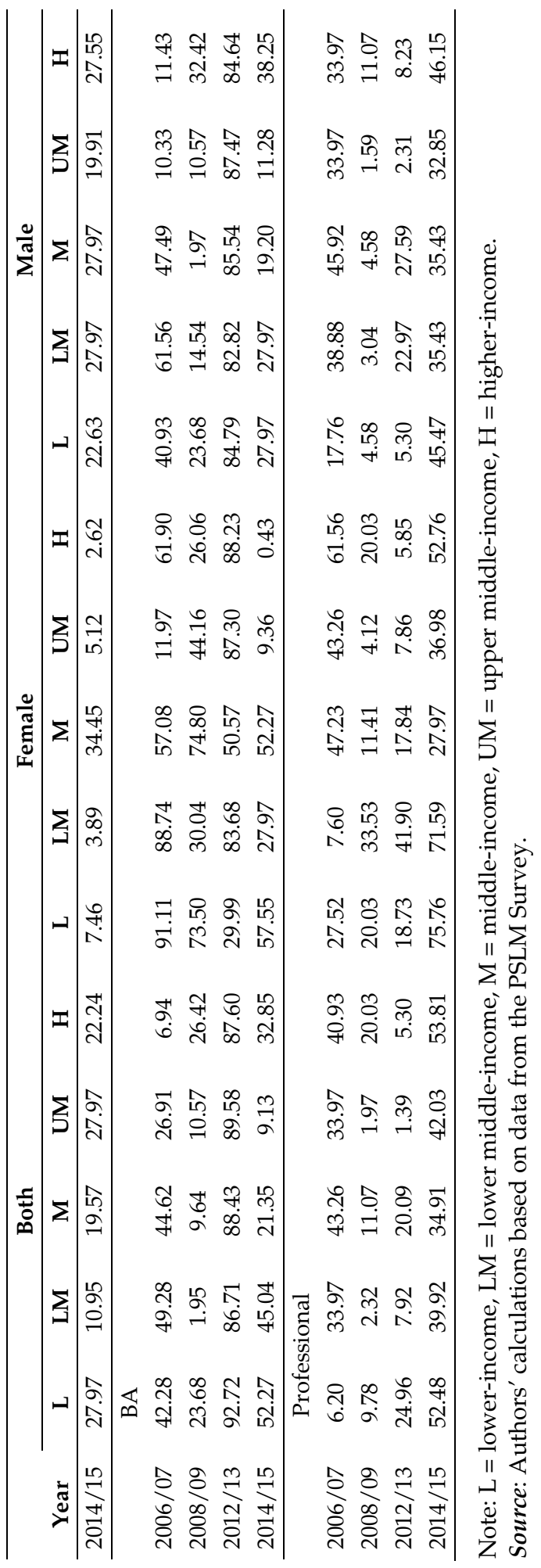


Table A9: Determinants of overall real earnings (GMM results)

\begin{tabular}{lccc}
\hline Variable & Both genders & Female & Male \\
\hline Employed labor force & $0.41^{* * *}$ & $0.58^{* * *}$ & $0.25^{* *}$ \\
Inflation (food) & $-2.23^{* * *}$ & $-3.24^{* * *}$ & $-1.97^{* * *}$ \\
Inflation (nonfood) & $1.47^{* * *}$ & $3.80^{* * *}$ & 0.91 \\
Rural & $0.71^{* * *}$ & 0.46 & $0.76^{* *}$ \\
J statistic & 3.16 & 2.37 & 2.31 \\
Observations & 209 & 208 & 209 \\
R squared & 0.58 & 0.52 & 0.45 \\
F stat & 23.07 & 18.59 & 15.65 \\
\hline
\end{tabular}

Source: Authors' calculations based on data from the PSLM Survey.

Table A10: Determinants of real earnings, by employment status (GMM results)

\begin{tabular}{|c|c|c|c|c|c|c|}
\hline Variable & $\begin{array}{c}\text { Both } \\
\text { genders }\end{array}$ & Female & Male & $\begin{array}{c}\text { Both } \\
\text { genders }\end{array}$ & Female & Male \\
\hline & \multicolumn{3}{|c|}{ Employers } & \multicolumn{3}{|c|}{ Self-employed (nonagriculture) } \\
\hline $\begin{array}{l}\text { Employed labor } \\
\text { force }\end{array}$ & $0.93^{* * *}$ & $1.87^{* * *}$ & $0.79^{* * *}$ & $0.50^{* * *}$ & $0.69^{* * *}$ & 0.28 \\
\hline Inflation (food) & $-5.81^{* * *}$ & -5.41 & $-6.52^{* * *}$ & $-1.33^{* *}$ & $-2.95^{* * *}$ & -0.87 \\
\hline Inflation (nonfood) & $4.85^{* * *}$ & -3.27 & $4.81^{* *}$ & 0.37 & $2.36^{* * *}$ & -0.17 \\
\hline Rural & 0.71 & $8.88^{* * *}$ & 0.47 & 0.45 & 0.55 & 0.25 \\
\hline J statistic & 4.32 & 0.09 & 3.48 & 1.48 & 1.31 & 1.84 \\
\hline Observations & 175 & 37 & 174 & 209 & 196 & 209 \\
\hline R squared & 0.72 & 0.64 & 0.68 & 0.56 & 0.62 & 0.38 \\
\hline \multirow[t]{2}{*}{ F stat } & 42.64 & 22.99 & 42.04 & 6.88 & 7.57 & 5.69 \\
\hline & \multicolumn{3}{|c|}{ Paid employees } & \multicolumn{3}{|c|}{ Self-employed (agriculture) } \\
\hline $\begin{array}{l}\text { Employed labor } \\
\text { force }\end{array}$ & $1.13^{* * *}$ & $1.00^{* * *}$ & $0.74^{* * *}$ & $0.65^{* * *}$ & $0.67^{* * *}$ & $0.46^{* * *}$ \\
\hline Inflation (food) & $-3.49^{* * *}$ & $-4.40^{* * *}$ & $-2.96^{* * *}$ & $-2.68^{* * *}$ & -0.64 & $-2.51^{* * *}$ \\
\hline Inflation (nonfood) & $1.92^{* * *}$ & $2.95^{* * *}$ & $1.41^{* * *}$ & $1.77^{* *}$ & 0.87 & $1.48^{*}$ \\
\hline Rural & $0.83^{* * *}$ & $0.81^{* * *}$ & $0.72^{* * *}$ & $1.33^{* * *}$ & $3.55^{* * *}$ & $1.54^{* * *}$ \\
\hline J statistic & 2.77 & 3.85 & 3.43 & 1.58 & 9.64 & 1.98 \\
\hline Observations & 209 & 208 & 209 & 208 & 173 & 208 \\
\hline R squared & 0.76 & 0.66 & 0.78 & 0.6 & 0.58 & 0.51 \\
\hline F stat & 58.93 & 36.17 & 51.63 & 19.32 & 15.9 & 13.34 \\
\hline
\end{tabular}

Source: Authors' calculations based on data from the PSLM Survey. 
Table A11: Determinants of real earnings, by province (GMM results)

\begin{tabular}{lcccc}
\hline Variable & Punjab & Sindh & KP & Balochistan \\
\hline Both genders & & & & \\
Employed labor force & $0.73^{* * *}$ & -0.1 & 0.33 & $0.52^{* * *}$ \\
Inflation (food) & $-4.34^{* * *}$ & -2.66 & $-3.03^{* * *}$ & -1.18 \\
Inflation (nonfood) & $3.76^{* * *}$ & 2.01 & $2.78^{* * *}$ & 0.56 \\
Rural & 0.47 & $1.88^{* *}$ & 0.51 & $0.93^{* *}$ \\
J statistic & 16.74 & 3.18 & 3.86 & 1.91 \\
Observations & 105 & 45 & 30 & 29 \\
R squared & 0.78 & -0.13 & 0.57 & 0.65 \\
F stat & 28.23 & 2.76 & 4.09 & 7.76 \\
\hline Female & & & & \\
Employed labor force & $0.47^{* * *}$ & -0.03 & $0.68^{* * *}$ & $0.68^{* * *}$ \\
Inflation (food) & $-3.64^{* * *}$ & $-9.36^{* * *}$ & $-3.60^{* * *}$ & -0.35 \\
Inflation (nonfood) & $2.93^{* * *}$ & $9.80^{* * *}$ & $4.09^{* * *}$ & 1.33 \\
Rural & 0.58 & -1.35 & -0.09 & $2.88^{* * *}$ \\
J statistic & 13.62 & 2.93 & 0.57 & 1.62 \\
Observations & 105 & 45 & 30 & 28 \\
R squared & 0.69 & 0.14 & 0.67 & 0.53 \\
F stat & 31.13 & 5.24 & 7.58 & 8.16 \\
\hline Male & & & & \\
Employed labor force & $0.74^{* * *}$ & 0.01 & -0.43 & $0.58^{* * * *}$ \\
Inflation (food) & $-4.34^{* * *}$ & -2.98 & $-3.87^{* * *}$ & -1.04 \\
Inflation (nonfood) & $3.38^{* * *}$ & 2.54 & $3.10^{*}$ & 0.2 \\
Rural & $0.64^{*}$ & $1.84^{* * *}$ & -1.06 & $1.03^{* * * *}$ \\
J statistic & 16.26 & 3.63 & 0.19 & 1.97 \\
Observations & 105 & 45 & 30 & 29 \\
R squared & 0.77 & 0.04 & -0.19 & 0.65 \\
F stat & 25.16 & 3.86 & 1.62 & 5.38 \\
\hline & & & &
\end{tabular}

Source: Authors' calculations based on data from the PSLM Survey. 
Table A12: Determinants of real earnings, by education level (GMM results)

\begin{tabular}{|c|c|c|c|c|c|c|c|}
\hline Variable & Illiterate & Primary & Secondary & Matric & $\begin{array}{c}\text { Inter- } \\
\text { mediate }\end{array}$ & Graduate & $\begin{array}{c}\text { Post- } \\
\text { graduate }\end{array}$ \\
\hline \multicolumn{8}{|l|}{ Both genders } \\
\hline $\begin{array}{l}\text { Employed labor } \\
\text { force }\end{array}$ & $0.44^{* * *}$ & $0.49^{* * *}$ & $0.50^{* * *}$ & 0.02 & $0.76^{* * *}$ & $0.94^{* * *}$ & $1.21^{* *}$ \\
\hline Inflation (food) & $-1.62^{* * *}$ & $-2.06^{* * *}$ & $-3.11^{* * *}$ & $-1.77^{* * *}$ & $-1.29^{*}$ & -2.11 & $-2.85^{* * *}$ \\
\hline $\begin{array}{l}\text { Inflation } \\
\text { (nonfood) }\end{array}$ & $1.06^{*}$ & $1.39^{* * *}$ & $2.34^{* * *}$ & 0.56 & 1.16 & 1.66 & $1.45^{*}$ \\
\hline Rural & $1.18^{* * *}$ & $1.09^{* * *}$ & $1.21^{* * *}$ & 0.5 & 0.46 & 0.01 & 0.23 \\
\hline J statistic & 2.43 & 3.5 & 2.79 & 1.75 & 0.32 & 0.4 & 0.71 \\
\hline Observations & 209 & 209 & 209 & 209 & 209 & 181 & 208 \\
\hline R squared & 0.63 & 0.62 & 0.64 & 0.18 & 0.68 & 0.94 & 0.77 \\
\hline F stat & 23.28 & 27.11 & 32.04 & 7.5 & 14.18 & 372.8 & 42.63 \\
\hline \multicolumn{8}{|l|}{ Female } \\
\hline $\begin{array}{l}\text { Employed labor } \\
\text { force }\end{array}$ & $0.81^{* * *}$ & $0.46^{* * *}$ & $0.87^{* * *}$ & $0.70^{* * *}$ & $1.21^{* * *}$ & $0.77^{* * *}$ & $0.82^{* * *}$ \\
\hline Inflation (food) & $-3.54^{* * *}$ & $-3.21^{* * *}$ & -1.73 & $-2.28^{* * *}$ & $-3.18^{* * *}$ & -3.67 & $-4.43^{* * *}$ \\
\hline $\begin{array}{l}\text { Inflation } \\
\text { (nonfood) }\end{array}$ & $6.05^{* * *}$ & 1.93 & $3.54^{* *}$ & 1.41 & $2.64^{* * *}$ & -0.43 & $3.11^{* * *}$ \\
\hline Rural & $1.23^{* *}$ & 0.43 & $1.74^{* * *}$ & 0.11 & $2.13^{* * *}$ & -0.28 & -0.15 \\
\hline J statistic & 2.29 & 3.84 & 2.94 & 4.55 & 1.01 & 2.34 & 3.2 \\
\hline Observations & 206 & 192 & 177 & 199 & 203 & 91 & 185 \\
\hline R squared & 0.55 & 0.45 & 0.53 & 0.45 & 0.62 & 0.82 & 0.71 \\
\hline F stat & 28.39 & 30.62 & 36.67 & 16.17 & 23.71 & 50.89 & 32.04 \\
\hline \multicolumn{8}{|l|}{ Male } \\
\hline $\begin{array}{l}\text { Employed labor } \\
\text { force }\end{array}$ & $0.46^{* * *}$ & $0.61^{* * *}$ & $0.50^{* * *}$ & 0.17 & $0.69^{* * *}$ & $0.93^{* * *}$ & $1.09^{* * *}$ \\
\hline Inflation (food) & $-1.81^{* * *}$ & $-2.27^{* * *}$ & $-3.18^{* * *}$ & $-2.07^{* * *}$ & -1.05 & -1.98 & $-3.01^{* * *}$ \\
\hline $\begin{array}{l}\text { Inflation } \\
\text { (nonfood) }\end{array}$ & 0.84 & $1.56^{* * *}$ & $2.35^{* * *}$ & 0.95 & 0.99 & 1.32 & 1.37 \\
\hline Rural & $1.16^{* * *}$ & $1.10^{* * *}$ & $1.22^{* * *}$ & 0.57 & 0.37 & 0.17 & 0.14 \\
\hline J statistic & 2.2 & 4.11 & 2.82 & 2.21 & 0.35 & 0.99 & 0.2 \\
\hline Observations & 209 & 209 & 209 & 209 & 209 & 179 & 208 \\
\hline $\mathrm{R}$ squared & 0.62 & 0.66 & 0.63 & 0.33 & 0.65 & 0.94 & 0.74 \\
\hline F stat & 19.49 & 32.49 & 31.77 & 9.41 & 10.45 & 325.53 & 39.77 \\
\hline
\end{tabular}

Source: Authors' calculations based on data from the PSLM Survey. 
Table A13: Determinants of real earnings, by age group (GMM results)

\begin{tabular}{|c|c|c|c|c|c|c|}
\hline \multirow[b]{2}{*}{ Variable } & \multicolumn{6}{|c|}{ Age cohort } \\
\hline & $10-19$ & $20-29$ & $30-39$ & $40-49$ & $50-59$ & 60 and $>$ \\
\hline \multicolumn{7}{|l|}{ Both genders } \\
\hline Employed labor force & $0.37^{* * *}$ & $0.51^{* * *}$ & $0.72^{* * *}$ & $0.85^{* * *}$ & $0.79^{* * *}$ & $1.12^{* * *}$ \\
\hline Inflation (food) & -0.81 & $-2.22^{* * *}$ & $-3.02^{* * *}$ & $-2.48^{* * *}$ & $-2.90^{* * *}$ & $-3.59^{* * *}$ \\
\hline Inflation (nonfood) & 0.95 & $1.62^{* * *}$ & $2.63^{* * *}$ & $1.39^{* * *}$ & $1.96^{* * *}$ & $3.33^{* * *}$ \\
\hline Rural & $0.68^{* *}$ & $0.55^{* *}$ & $0.91^{* * *}$ & $0.44^{*}$ & 0.45 & $0.73^{* * *}$ \\
\hline J statistic & 1.74 & 8.26 & 4.09 & 3.54 & 2.88 & 2.13 \\
\hline Observations & 209 & 209 & 209 & 209 & 209 & 209 \\
\hline $\mathrm{R}$ squared & 0.42 & 0.65 & 0.69 & 0.73 & 0.65 & 0.7 \\
\hline F stat & 9.02 & 26.01 & 29.72 & 50.48 & 30.76 & 54.93 \\
\hline \multicolumn{7}{|l|}{ Female } \\
\hline Employed labor force & $0.47^{* * *}$ & $0.71^{* * *}$ & $0.59^{* * *}$ & $0.69^{* * *}$ & $0.75^{* * *}$ & $0.83^{* * *}$ \\
\hline Inflation (food) & $-2.66^{* *}$ & $-2.72^{* * *}$ & $-3.75^{* * *}$ & $-3.32^{* * *}$ & $-5.64^{* * *}$ & -0.53 \\
\hline Inflation (nonfood) & $3.37^{* *}$ & $3.83^{* * *}$ & $4.08^{* * *}$ & $3.64^{* * *}$ & $8.26^{* * *}$ & 2.35 \\
\hline Rural & 0.59 & -0.4 & $1.09^{* *}$ & 0.16 & 1.05 & -0.79 \\
\hline J statistic & 2.76 & 3.87 & 2.88 & 3.55 & 3.92 & 1.61 \\
\hline Observations & 198 & 206 & 206 & 206 & 194 & 144 \\
\hline R squared & 0.29 & 0.51 & 0.45 & 0.56 & 0.35 & 0.35 \\
\hline F stat & 8.13 & 16.97 & 23.12 & 31.67 & 17.8 & 8.55 \\
\hline \multicolumn{7}{|l|}{ Male } \\
\hline Employed labor force & $0.40^{* * *}$ & $0.33^{* * *}$ & $0.80^{* * *}$ & $1.25^{* * *}$ & $0.90^{* * *}$ & $1.21^{* * *}$ \\
\hline Inflation (food) & -1.02 & $-1.85^{* * *}$ & $-3.22^{* * * *}$ & $-3.25^{* * *}$ & $-3.18^{* * *}$ & $-4.06^{* * *}$ \\
\hline Inflation (nonfood) & 1.17 & 0.8 & $2.51^{* * *}$ & $1.54^{* * *}$ & $1.79^{* * *}$ & $3.45^{* * *}$ \\
\hline Rural & $0.65^{*}$ & $0.62^{* *}$ & $0.99^{* * *}$ & $0.54^{* *}$ & 0.47 & $0.66^{* *}$ \\
\hline J statistic & 0.97 & 6.08 & 3.5 & 4.61 & 2.59 & 1.9 \\
\hline Observations & 209 & 209 & 209 & 209 & 209 & 209 \\
\hline $\mathrm{R}$ squared & 0.42 & 0.52 & 0.69 & 0.68 & 0.65 & 0.67 \\
\hline F stat & 9.31 & 16.45 & 27.11 & 28.89 & 23.27 & 45.88 \\
\hline
\end{tabular}

Source: Authors' calculations based on data from the PSLM Survey. 


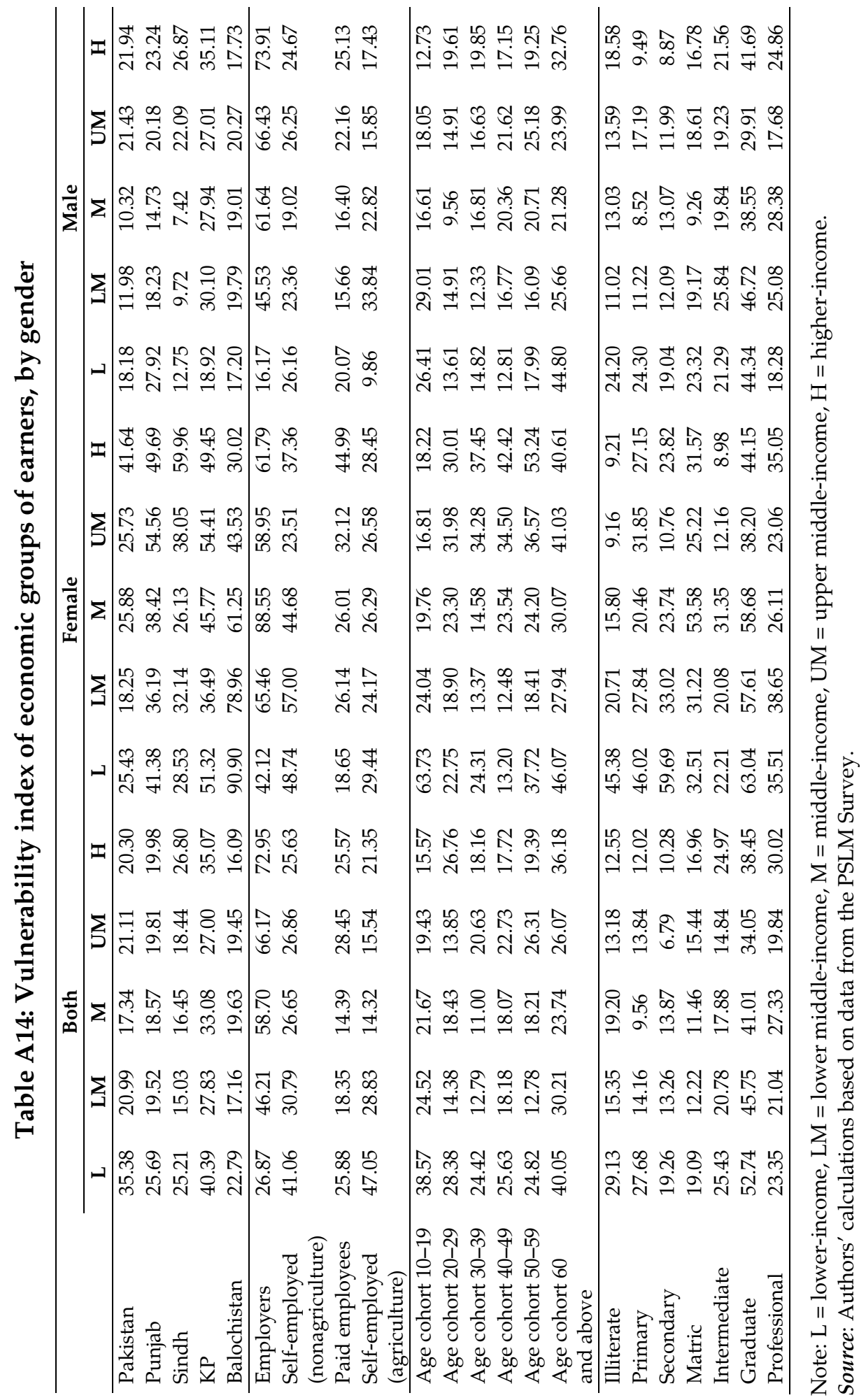




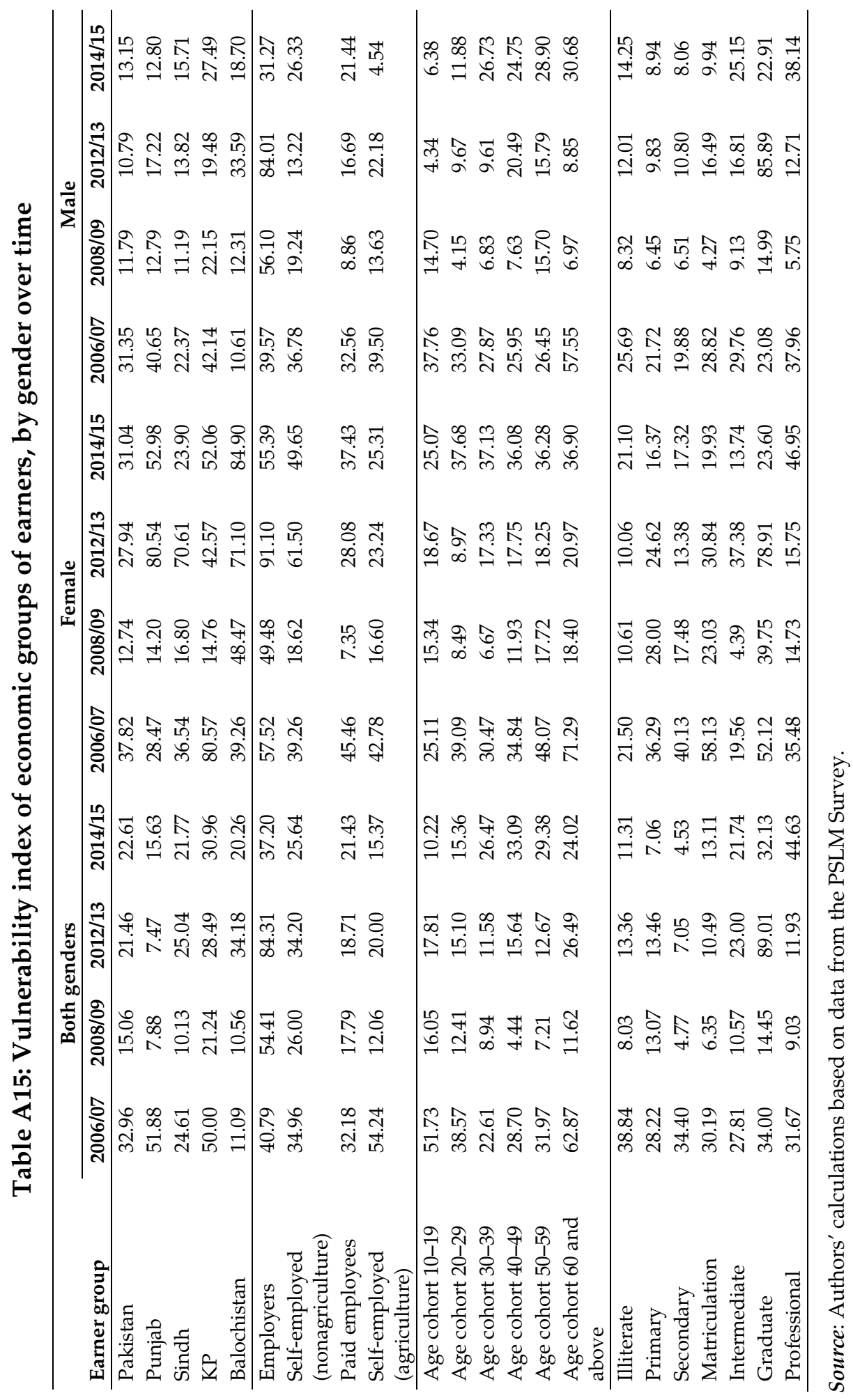

